\title{
PENGARUH PROFITABILITAS TERHADAP NILAI PERUSAHAAN DENGAN DANA COORPORATE SOCIAL RESPONBILITY (CSR) SEBAGAI VARIABEL MODERATING PADA SEKTOR PERTAMBANGAN DAN SEKTOR INDUSTRI DASAR DAN KIMIA DI INDONESIA
}

\author{
Isti Dahliatul Khasanah ${ }^{1 *}$, Indah Yuliana ${ }^{1}$ \\ Jurusan Manajemen Fakultas Ekonomi, Universitas Negri Islam Maulana Malik Ibrahim Malang \\ *Email corresponding author: istidahliakhasanah405@gmail.com \\ Diterima 08/11/2019 Direvisi 30/12/2019 Diterbitkan 31/01/2020
}

\begin{abstract}
Abstrak
Penelitian ini bertujuan untuk menyelidiki pengaruh Profitabilitas terhadap nilai perusahaan dengan dana coorporate social responbility (CSR) apakah memperlemah ataupun justru memperkuat. Penelitian ini terdiri dari 15 sampel perusahaan sektor pertambangan dan sektor industri dasar dan kimia dengan menggunakan teknik purposive sampling selama periode 2016-2018 sementara metode analisis yang kami gunakan adalah analisis statistic deskriptif dan partial least square (PLS). Hasil penelitian kami menunjukkan bahwa profitabilitas yang menggunakan indicator Return On Asset (ROA) dan Return On Equity (ROE) berpengaruh signifikan dan positif terhadap nilai perusahaan, dana Coorporate Social Responbility tidak signifikan dan berpengaruh negatif terhadap nilai perusahaan, dana Coorporate Social Responbility mampu memoderasi secara positif atau memperkuat hubungan profitabilitas terhadap nilai perusahaan. Pada variabel yang digunakan dalam penelitian ini menunjukan bahwa variabel tersebut dapat menjelaskan nilai perusahaan sebesar $44,3 \%$ sedangkan sisanya sebesar $56,7 \%$ dipengaruhi oleh varibel lain yang tidak terdapat dalam model penelitian ini.

Kata Kunci: Return On Asset (ROA), Return On Equity (ROE), Dana Coorporate Social Responbility, Nilai Perusahaan
\end{abstract}

\begin{abstract}
This study aims to investigate the effect of profitability on firm value with coorporate social responsibility (CSR) funds, whether it weakens or actually strengthens. This study consisted of 15 samples of mining sector companies and basic and chemical industry sectors using purposive sampling techniques during the 2016-2018 period while the analytical method we used was descriptive statistical analysis and partial least square (PLS). Our results show that profitability that uses the Return On Asset (ROA) and Return On Equity (ROE) indicators has a significant and positive effect on firm value, Corporate Social Responsibility funds are not significant and negatively affects company value, Corporate Social Responsibility funds are able to moderate moderately positive or strengthen the relationship of profitability to the value of the company. The variables used in this study indicate that these variables can explain the value of the company by $44.3 \%$ while the remaining $56.7 \%$ is influenced by other variables not contained in this research model.
\end{abstract}

Keywords: Return On Assets (ROA), Return On Equity (ROE), and Corporate Social Responsibility, Company Value 


\section{PENDAHULUAN}

Indonesia jika dilihat dari CSR-nya semakin meningkat baik dalam kualitas maupun kuantitas. Selain keragaman kegiatan dan pengelolaannya semakin bervariasi, dilihat dari kontribusi finansial, jumlahnya semakin besar. Pada tahun 2001 PIRAC dalam penelitianya menunjukkan bahwa dana CSR di Indonesia mencapai sekitar lebih dari 115 miliar rupiah atau jika dalam Dolar sekitar 11.5 juta dollar AS. Dari 279 kegiatan sosial yang terekam oleh media massa, Indonesia merupakan salah satu dari 180 perusahaan yang dibelanjakan. Meskipun dana tersebut masih sangat kecil jika dibandingkan dengan dana CSR dinegara-negara lain khususnya di Amerika Serikat. Perkembangan CSR di Indonesia cukup menggembirakan jika dilihat dari angka kumulatif tersebut, angka rata-rata perusahaan yang menyumbangkan dana bagi kegiatan CSR adalah sekitar 413 juta atau sekitar 640 juta rupiah per kegiatan. Sebagai perbandingan, di AS porsi sumbangan dana CSR pada tahun 1998 mencapai 21.51 miliar dollar dan tahun 2000 mencapai 203 miliar dollar atau sekitar 2.030 triliun rupiah (Saidi, 2004:64). Dalam setiap negara pastinya harus bersedia membayar CSR-nya berikut data ketersediaan dari setiap negara untuk membayar CSR.

Jika dilihat dari kasus di Indonesia kendala dari CSR yang paling mendasar terletak pada komitmen, perusahaan. Jika perusahaan tidak memiliki komitmen terhadap lingkungan sekitar, maka tanggung jawab dan kepedulian sosial itu pun juga tidak ada. Secara umum, sejak 1990-an, masalah tanggung jawab sosial perusahaan (CSR) telah menerima perhatian yang signifikan dari akademisi dan praktisi (Ahmad, 2010). Setelah itu, sikap manajer perusahaan terhadap kegiatan CSR terus berubah. Akibatnya, CSR dipandang sebagai dialog antara organisasi dan masyarakat pada umumnya (Gray et al., 1995b).

Lin et al. (2009: 57) menyatakan bahwa hubungan antara CSR dan kinerja keuangan adalah salah satu masalah utama dan topik penelitian di bidang tanggung jawab sosial saat ini. Tidak hanya konsep CSR telah diakui oleh publik, tetapi juga telah dilaporkan oleh perusahaan (Lee dan Park, 2009: 105). Salah satu faktor terpenting dalam berjalannya kegiatan sosialnya perusahaan adalah kemampuan pengelolaan keuangan perusahaan, karena profitabilitas akan mempengaruhi besar kecilnya dana dalam kegitan CSR. Jika kinerja keuangan suatu perusahaan baik maka secara tidak langsung semakin baik pula nilai perusahaannya. Dalam teori kebutuhan dari Maslow ketika kebutuhan dasar perusahaan sudah tercapai yaitu profit sesuai ditargetkan maka tingkat selanjutnya perusahaan harus melanjutkan memenuhi kebutuhannya sampai mencapai kebutuhan tanggung jawab sosial perusahaan. (Arika \& I Putu, 2017). Sejalan dengan penelitian yang dilakukan oleh Roitto (2013); Chauhan dan Amit (2014); Andreas dkk. (2015); Ayu dan Sauarjana (2017) yang menyatakan bahwa corporate social responbility berpengaruh positif terhadap Profitabilitas.

CSR dapat memiliki efek positif pada citra perusahaan (Linthicum et al., 2010: 161). Wu dan Shen (2013: 3529) menyatakan bahwa penerapan CSR oleh perusahaan dapat bermanfaat bagi kinerja makro dan mikro. Berkenaan dengan kinerja makro, perusahaan dapat berkontribusi secara signifikan dalam meningkatkan nilai lingkungan dan sosial. Dalam hal kinerja mikro, perusahaan dapat meningkatkan reputasi mereka sendiri dan merekrut karyawan yang berkualitas. CSR juga dapat meningkatkan peran perusahaan dalam meningkatkan kesejahteraan sosial, yang dapat memiliki efek positif pada pemangku kepentingan (Lin et al., 2009: 57).

Penelitian Deswanto dan Siregar (2018), Clarkson et al. (2011) menyatakan bahwa perusahaan dengan profitabilitas tinggi mampu menanggung biaya yang terkait dengan persiapan pengungkapan lingkungan objektif selain itu, perusahaan dengan kinerja lingkungan yang tinggi bertekad untuk menjaga agar investor dan pemangku kepentingan lainnya mendapat informasi dengan baik melalui pengungkapan lingkungan yang lebih sukarela dibandingkan dengan 


\section{PERFORMANCE}

Jurnal Personalia, Financial, Operasional,

Marketing dau Sistem Informasi

Performance. Volume 27 Nomor 1 Tahun 2020, 51-59

perusahaan dengan kinerja lingkungan yang lebih rendah. Selain itu penelitian Zallom (2016), Bird et al. (2007), Scholtens (2008), Lin et al. (2009) menyatakan bahwa CSR mengurangi profitabilitas (nilai pasar) dalam sebuah perusahaan dikarenakan sebuah perusahaan tersebut tidak mematuhi peraturan lingkungan dan karenanya dapat ditolak oleh pasar. Selain itu, efek negatif mendukung teori liberal, yang menunjukkan bahwa kegiatan CSR melibatkan biaya dan dapat memperburuk posisi kompetitif perusahaan,

Berdasarkan penelitian terdahulu yang telah dijelaskan terdapat perbedaan hasil mengenai pengaruh Dana Corporate Social Responbility (CSR) terhadap nilai perusahaan dengan profitabilitas sebagai variable intervening, variabel profitabilitas diukur dengan menggunakan Return On Asset (ROA) dan Return On Equity (ROE). sehingga ditemukan gap research dari kedua penelitian terdahulu tersebut. Selain itu, penelitian ini juga ingin membuktikan apakah perusahanperusahaan publik sektor lainnya melakukan CSR yang jauh lebih banyak (khususnya CSR lingkungan) dibandingkan perusahaan pengelola sumber daya alam yang sebenarnya memiliki tanggung jawab sosial yang lebih besar karena nantinya akibat yang ditimbulkan juga semakin besar. Sehingga dalam penelitian ini, akan mengangkat permasalahan tentang "Pengaruh Profitabilitas Terhadap Nilai Perusahaan dengan Dana Corporate Social Responbility (CSR) sebagai Variabel Moderating Pada Sektor Pertambangan dan Sektor Industry dasar dan Kimia Di Indonesia"

\section{TINJAUAN PUSTAKA DAN PERUMUSAN HIPOTESIS}

\section{Pengaruh Profitabilitas terhadap Nilai Perusahaan}

Rasio profitabilitas diukur dengan Returs On Asset (ROA) dan Return On Equity (ROE) yang digunakan sebagai proksi, kinerja ROA digunakan untuk mengukur presentase laba dan pajak berjalan dengan total asset. Sedangkan Kinerja ROE digunakan untuk mengukur presentase laba dan pajak berjalan dengan total equity. ROE ini menunjukkan seberapa banyak keuntungan yang dapat dihasilkan oleh perusahaan dari setiap satu rupiah yang diinvestasikan oleh para pemegang saham. Perhitungan ROE dalam Penelitian Nurahman et al., (2018) dinyatakan dengan persen (\%).

Penelitian Nurrahman, et al., (2018) menyatakan bahwa Profitabilitas berpengaruh signifikan terhadap Nilai perusahaan. Hal ini menunjukkan bahwa semakin tinggi profitabilitas perusahaan maka dapat meningkatkan nilai perusahaan. Begitu juga dengan penelitian Lubis et al., (2017), Indriyani (2017), Wijaya dan Panji (2015), Sari (2015), Nofrita (2013), Rizqia, dkk (2013), Mardiyati (2012) dan Setiabudi dan Dian (2012) mengemukkan bahwa profitabilitas signifikan dan berpengaruh positif terhadap nilai perusahaan. Oleh Karena itu, Hipotesis kedua dalam penelitian ini disajikan dibawah ini.

H1: Profitabilitas berpengaruh signifikan positif terhadap nilai perusahaan

\section{Moderasi Hubungan Profitabilitas terhadap Nilai Perusahaan}

Dalam penelitian menyatakan Umar (2018) menyatakan bahwa adanya hubungan positif antara Dana CSR dengan profitabilitas. Hal ini sejalan dengan penelitian Deswanto dan Siregar 2018, Mukherjee et al., (2017), Ayu dan Suarjana (2017), Febrianti (2016), Andreas dkk (2015), Chauhan dan Amit (2014), Rai dan Bansal (2014), Hakim dan Nugroho (2014), dan Clarkson et al. (2007) yang juga mengemukkan bahwa ada hubungan positif antara csr dan profitabiltas. Sedangkan Syamni dkk (2018), Arika dan I Putu (2017), Kabir dan Qoyum (2016), dan Folajin et al., (2014) menyatakan bahwa CSR tidak memiliki hubungan terhadap profitabiltas. Selain itu, penelitian Ayu dan Suarjana (2017) menyebutkan bahwa Corporate Social Responbility (CSR) berpengaruh positif dan signifikan terhadap Nilai Perusahaan. Penelitian tersebut sejalan dengan penelitian yang dilakukan oleh Murnita dan I Made (2018), Romana (2017), Puspaningrum (2017), dan Nahda dan Harjito (2011). Sedangkan penelitian yang dilakukan oleh Zallom (2016), Bird et al. (2007), Scholtens (2008) dan Lin et al. (2009) mengemukakan bahwa Coorporate Social Responbility (CSR) berpengaruh negatif dan tidak signifikan terhadap nilai perusahaan. 
Jurnal Personalia, Financial, Operasional,

Marketing dau Sistem Informasi

Performance. Volume 27 Nomor 1 Tahun 2020, 51-59

Berdasarkan penelitian tersebut maka hipotesis penelitian kedua dalam peneltian disajikan dibawah ini:

H2: Dana Coorporate Social Responbility (CSR) berpengaruh signifikan positif terhadap nilai perusahaan

H3: Dana Coorporate Social Responbility (CSR) mampu memperkuat hubungan profitabilitas dengan nilai perusahaan

\section{METODE PENELITIAN}

Populasi yang digunakan sebagai bahan penelitian ini adalah perusahaan sektor pertambangan dan sektor industry dasar dan kimia yang terdaftar di Bursa Efek Indonesia periode 2016-2018. Teknik sampel yang digunakan adalah purposive sampling. Teknik analisis data yang digunakan dalam penelitian ini adalah menggunakan statistik deskriptif dan Partial Least Square (PLS) untuk pengujian model pengukuran dan structural. Kerangka konseptual penelitian akan disajikan dalam Gambar 1 dibawah ini.

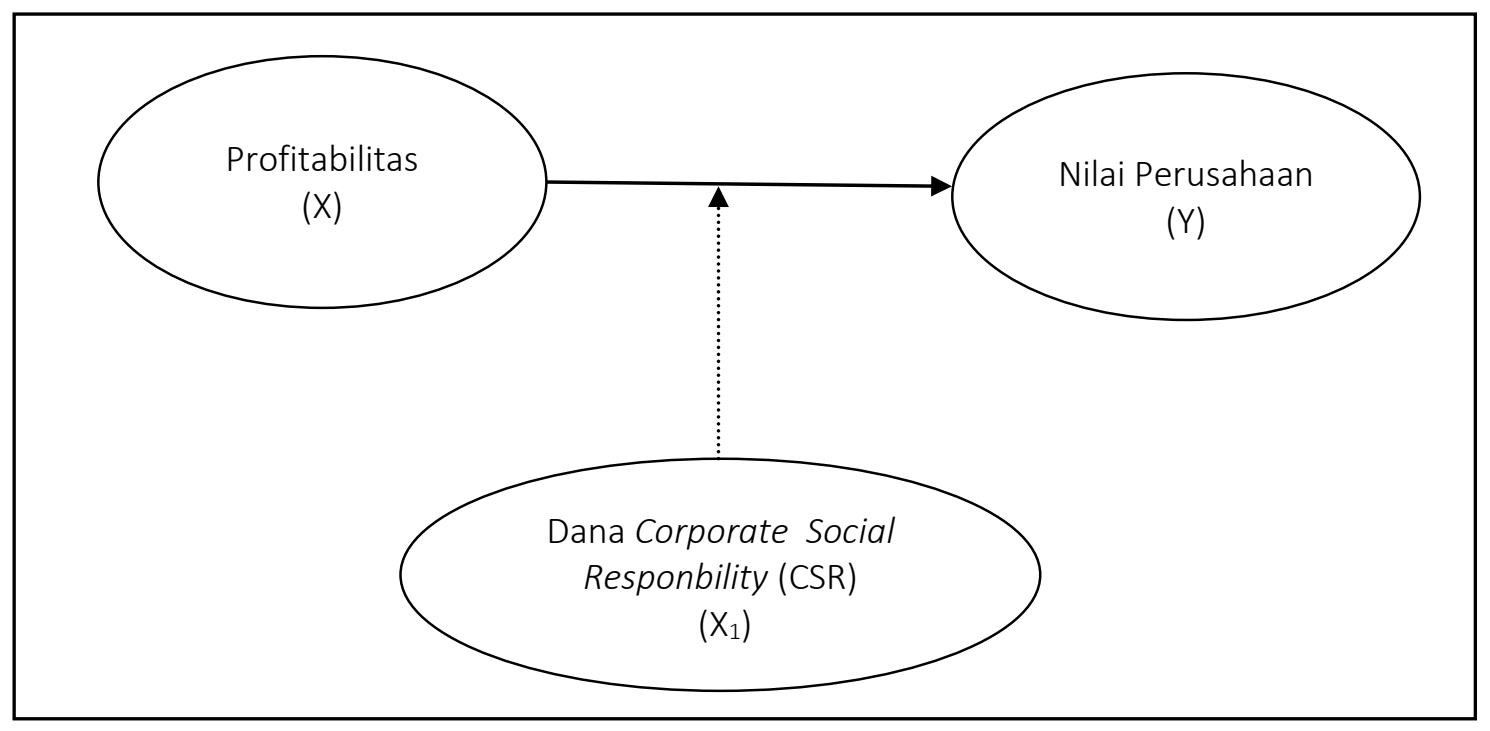

Gambar 1. Kerangka Konseptual

\section{HASIL DAN PEMBAHASAN}

Hipotesis pertama menyatakan bahwa profitabilitas berpengaruh signifikan positif terhadap nilai perusahaan. Hasil pengujian menunjukkan bahwa variabel profitabilitas diukurdengan indicator Return On Asset (ROA) dan Return On Equity (ROE) memiliki nilai T statistik 5,203 dan pvalue sebesar 0.000 , sedangkan nilai t-tabel sebesar 1.67943 dan nilai $p$-value kurang dari 0,05 atau 5\%. Hasil menujukkan bahwa nilai Tstatistik $>$ T-tabel dan P-value $<0,05$. Hal tersebut menunjukkan bahwa variabel profitabilitas secara langsung berpengaruh siginifikan dan arah positif terhadap nilai perusahaan atau dengan kata lain $\mathrm{H} 1$ diterima.

Berdasarkan pengujian hipotesis yang pertama dapat disimpulkan bahwa terdapat pengaruh signifikan positif dari variabel profitabilitas terhadap nilai perusahaan. Dari pengujian hiipotesis pertama terbukti bahwa memang profitabilitas berpengaruh signfian dan positif. Hasil penelitian ini menyimpulkan bahwa menerima hipotesis pertama diukur dengan menggunakan indikator Return On Asset (ROA) dan Return On Equity (ROE) mempunyai pengaruh positif terhadap nilai perusahaan pada Sektor Pertambangan dan Sektor Industry dasar dan Kimia yang terdaftar di bursa Efe Indonesia tahun 2016-2018. Hal ini menunjukkan bahwa Perusahaan yang mampu meningkatkan laba dan menjaga kestabilan dari kenaikan laba dalam laporan keuangan dapat 
Performance. Volume 27 Nomor 1 Tahun 2020, 51-59

memberikan sinyal positif kepada para investor berkaitan dengan kinerja perusahaan dan pertumbuhan prospek usaha di masa mendatang (Rizqia dkk., 2013). Hasil penelitian ini sejalan dengan penelitian Nurrahman, et al., (2018) menyatakan bahwa Profitabilitas berpengaruh signifikan terhadap Nilai perusahaan. Hal ini menunjukkan bahwa semakin tinggi profitabilitas perusahaan maka dapat meningkatkan nilai perusahaan. Begitu juga dengan penelitian Lubis et al., (2017), Indriyani (2017), Wijaya dan Panji (2015), Sari (2015), Nofrita (2013), Rizqia, dkk (2013), Mardiyati (2012) dan Setiabudi dan Dian (2012) mengemukkan bahwa profitabilitas signifikan dan berpengaruh positif terhadap nilai perusahaan.

Hipotesis kedua menyatakan bahwa dana corporate social responbility berpengaruh sifnifikan positif terhadap nilai perusahaan. Hasil pengujian menunjukkan T statistic 1,252 dan p-value 0,106. Sedangkan nilai t-tabel sebesar 1.67943 dan nilai p-value kurang dari 0,05 atau 5\%. Hasil menujukkan bahwa nilai Tstatistik < T-tabel dan P-value $<0,05$. Hal tersebut menunjukkan bahwa variabel dana corporate social responbility tidak signifikan dan negaitif atau dengan kata lain $\mathrm{H} 2$ ditolak.

Pengujian hipotesis yang kedua dapat disimpulkan bahwa terdapat pengaruh tidak signifikan dan berpengaruh negatif dari variabel dana Coorporate Social Responbility terhadap nilai perusahaan. Dari pengujian hipotesis kedua dapat disimpulkan bahwa menolak hipotesis kedua yang menduga bahwa dana Coorporate Social Responbility berpengarug signifikan positif terhadap nilai perusahaan pada Sektor Pertambangan dan Sektor Industry dasar dan Kimia yang terdaftar di bursa Efe Indonesia tahun 2016-2018. Hal ini berati dana Coorporate Social Responbility meskipun jumlahnya besar tidak akan mempengaruhi nilai dari suatu perusahaan. Sejalan dengan penelitian yang dilakukan oleh Zallom (2016), Bird et al. (2007), Scholtens (2008) dan Lin et al. (2009) mengemukakan bahwa Social Responbility (CSR) berpengaruh negatif dan tidak signifikan terhadap nilai perusahaan. Linthicum et al. $(2010,175)$ bahwa pengeluaran untuk tanggung jawab sosial tidak konsisten dengan memaksimalkan pengembalian pemegang saham selain itu dalam kegiatannya tergantung bagaimana perusahaan bisa memanfaatkan dana CSR untuk melaksanakan kegiatan yang secara tidak langsung nantinya dapat meningkatkan daya saing mereka dan nilai perusahaannnya.

Hipotesis ketiga menyatakan bahwa dana corporate social responbility memperlemah ataupun memperkuat hubungan profitabilitas terhadap nilai perusahaan. Hasil menunjukkan bahwa variabel efek moderasi memiliki nilai T statistik 3,029 dan p-value sebesar 0.001, sedangkan nilai t-tabel sebesar 1.67943 dan nilai p-value kurang dari 0,05 atau 5\%. Hasil menujukkan bahwa nilai Tstatistik $>$ T-tabel dan P-value $<0,05$. Hal tersebut menunjukkan bahwa variabel dana corporate social responbility secara langsung memperkuat hubungan terhadap nilai perusahaan atau dengan kata lain $\mathrm{H} 3$ diterima.

Pengujian hipotesis ketiga merumuskan bahwa dana Coorporate Social Responbility dapat memoderasi dengan dapat memperkuat ataupun memperlemah hubungan profitabilitas terhadap nilai perusahaan. Dari hasil pengujian mennjukan bahwa terdapat pengaruh signifikan positif artinya variabel dana Coorporate Social Responbility mampu momederasi secara positif atau memperkuat hubungan profitabilitas terhadap nilai perusahaan, maka dapat disimpulkan bahwa hipotesis ketiga diterima dan variabel variabel dana Coorporate Social Responbility memperkuat hubungan profitabilitas terhadap nilai perusahaan Sektor Pertambangan dan Sektor Industry dasar dan Kimia yang terdaftar di bursa Efe Indonesia tahun 2016-2018. Dalam meningkatkan nilai perusahaan usaha yang dilakukan terkadang tidak dibarengi dengan menjaga keberlangsungan sumber-sumber yang ada. Pada era sekarang perusahaan serta masyarakat mulai peduli terhadap lingkungan, CSR merupakan hal yang wajib dilakukan dan bukan sekedar pilihan sukarela bagi perusahaan. Corporate Social Responsibility yang diusung oleh perusahaan tergantung pada biaya atau dana yang dialokasikan terhadap program tersebut, semakin banyak alokasi dana perusahaan, semakin besar program Corporate Social Responsibility yang akan dilaksanakan 


\section{PERFORMANCE}

Jurnal Personalia, Financial, Operasional,

Marketing dau Sistem Informasi

Performance. Volume 27 Nomor 1 Tahun 2020, 51-59

perusahaan (Adiatma, 2015). Dari biaya yang dialokasikan kepada program CSR akan secara tidak langsung akan meningkatkan citra dari sebuah perusahaan tersebut. Hadi (2011) menyatakan bahwa biaya sosial yang dikeluarkan perusahaan dapat meningkatkan kinerja ekonomi perusahaan. Biaya sosial perusahaan akan menjadi beban yang mengurangi pendapatan yang menyebabkan tingkat profit perusahaan akan menurun. Akan tetapi, dengan terlaksananya CSR maka citra perusahaan akan baik yang mengakibatkan loyalitas konsumen semakin tinggi. Dengan meningkatnya loyalitas konsumen maka penjualan pun akan semakin membaik lebih-lebih akan meningkat.

\section{KESIMPULAN}

Berdasarkan analisis data serta pembahasan hasil pengujian hipotesis yang dilakukan maka dapat disimpulkan bahwa pertama, pengaruh profitabilitas terhadap nilai perusahaan berpengaruh signifikan dan positif artinya semakin besar profit yang diperoleh suatu perusahaan maka semakin meningkat pula nilai perusahaan, Kedua pengaruh dana Coorporate Social Responbility terhadap nilai perusahaan berpengaruh negative dan tidak signifian artinya meskipun dana Coorporate Social Responbility suatu perusahan besar maka tida akan memperngaruhi nilai perusahaan, justru biasanya malah membuat perusahaan rugi karena kesalahan perusahaan dalam memanfaatkan dananya. Ketiga dana Coorporate Social Responbility mampu momederasi secara positif atau memperkuat hubungan profitabilitas terhadap nilai perusahaan, dana Coorporate Social Responbility yang dikeluarkan perusahaan dapat meningkatkan kinerja perusahaan. dana Coorporate Social Responbility perusahaan akan menjadi beban yang mengurangi pendapatan yang menyebabkan tingkat profit perusahaan akan menurun. Akan tetapi, dengan terlaksananya CSR maka citra perusahaan akan baik yang mengakibatkan loyalitas konsumen semakin tinggi. Dengan meningkatnya loyalitas konsumen maka penjualan pun akan semakin membaik lebih-lebih akan meningkat.

Keterbatasan penelitian ini adalah (1) penelitian ini hanya dilakukan pada perusahaan sector pertambangan dan setor bahan dasar dan industry, (2) penelitian ini hanya menggunakan periode jangka waktu yang pendek sehingga akan mempengaruhi sampel penelitian, (3) penelitian ini hanya menggunakan satu variabel keuangan sehingga akan mempengaruhi hasil pengolahan data. Saran untuk peneliti selanjutnya yaitu (1) peneliti berikutnya dapat melakukan dengan objek yang sangat luas sehingga hasilnya lebih baik, (2) peneliti selanjutnya menggunakan periode yang lebih panjang agar dan (3) menambah variabel pengujian selain itu juga menggunakan proksi yang berbeda.

\section{DAFTAR PUSTAKA}

Ahmad, Wong Lai Cheng Jamilah. (2010). Incorporating stakeholder approach in corporate social responsibility (CSR): a case study at multinational corporations (MNCs) in Penang. Social Responsibility Journal, Vol. 6 Iss 4 pp. 593-610.

Andreas, Hans Hananto, Usil Sis Sucahyo, \& Delima Elisabeth. (2015). Corporate Social Responsibility Dan Profitabilitas. Fakultas Ekonomika dan Bisnis - Universitas Kristen SatyaWacana. Vol.15, No.1

Arika, Ni Luh Putu Fivetina Wulan Ade \& I Putu Sudana. (2017). Industry Profile Dan Corporate Social Responsibility Expenditure. E-Jurnal Akuntansi Universitas Udayana. Vol.19.2. 
Jurnal Personalia, Financial, Operasional,

Marketing dau Sistem Informasi

Performance. Volume 27 Nomor 1 Tahun 2020, 51-59

Ayu, Dea Putra, Suarjaya Gede. (2017) Pengaruh Profitabilitas Terhadap Nilai Perusahaan Dengan Corporate Social Responsibility Sebagai Variabel Mediasi Pada Perusahaan Pertambangan. E-Jurnal Manajemen Unud, Vol. 6, No. 2.

Bird, R., Hall, A.D., Momente, F. \& Reggiani, F. (2007). What Corporate Social Responsibility Activities are Valued by The Market?. Journal of Business Ethics, 76, pp.189-206.

Chauhan, Swati \& Amit. (2014). A Relational Study of Firm's Characteristics and CSR Expenditure. Procedia Economics and Finance, 11:23-32

Clarkson, P.M., Overell, M.B. \& Chapple, L. (2011). Environmental Reporting and its Relation to Corporate Environmental Performance. ABACUS, 47, (1), pp.27-56

Deswanto, Refandi Budi, \& Siregar Sylvia Veronica. (2018). The associations between environmental disclosures with financial performance, environmental performance, and firm value. Social Responsibility Journal, Vol. 14 Issue: 1, pp.180-193.

Febrianti, Dwi. (2016). Pengaruh Kinerja Keuangan Terhadap Corporate Social Expenditure dan Corporate Social Responsibility Disclosure. (Studi Empiris Pada Perusahaan Pertambangan Yang Terdaftar di Bursa Efek Indonesia tahun 2012-2015). Universitas Muhammadiyah Yogyakarta.

Folajin, Oyetayo.,Ibiyote, Oluwaseun., \& Dunsin. (2014). Corporate Social Responsibility And Organizational Profitability: An Empirical investigation of United Bank For Africa (UBA) Plc. International journal of ac

Gray, R.H., Kouhy, R. \& Lavers, S. (1995b). Constructing a research database of social and environmental reporting by UK companies: a methodological note. Accounting, Auditing \& Accountability Journal, Vol. 8 No. 2, pp. 78-101.

Hakim, Halim Farizan \& Nugroho, Anggoro Budi. (2014). The Effect Corporate Social Responsibility Expense To Corporate Profitability (ROA) And Stock Return (Case Study In Each 9 Company Sectors In The Stock Exchange In Q1 2009 until Q1 2014). Journal of Business and Management Vol 3, No 6, 2014:620-632.

Indriyani, Eka. (2017). Pengaruh Ukuran Perusahaan dan Profitabilitas Terhadap Nilai Perusahaan. Jurnal Ilmu Akuntansi Volume 10 (2).

Kabir, Rezaul \& Qayum, Abdul. (2016). CSR Corporate and Bank's Financial Performance: A comparative study on Islamic Bank of Bangladesh. Internasional Scholar Journal of Accounting and Finance, Vol. 2. No 2, 1-12

Lee,S. \& Park, S-Y. (2009). Do Socially Responsible Activities Help Hotels and Casinos Achieve Their Financial Goals?. International Journal of Hospitability Management, 28, pp.105-112.

Lin, C-H., Yang, H-L. \& Liou, D-Y. (2009). The Impact of Corporate Social Responsibility on Financial Performance: Evidence From Business in Taiwan. Technology In Society, 32, pp.56-63.

Linthicum, C., Reitenga, A. \& Sanchez, J. (2010). Social responsibility and corporate reputation: The case of the Arthur Andersen Enron audit failure. Journal of Accounting and Public Policy, 29, pp. 160-176. 
Jurnal Personalia, Financial, Operasional,

Marketing dau Sistem Informasi

Performance. Volume 27 Nomor 1 Tahun 2020, 51-59

Lubis, Ignatius Leonardus, Bonar M Sinaga \& Hendro Sasongko. (2017). Pengaruh Profitabilitas, Sruktur Modal, Dan Likuiditas Terhadap Nilai Perusahaan. Jurnal Aplikasi Bisnis dan Manajemen, Vol. 3 No. 3.

Mardiyati, Umi. Gatot Nizar Ahmad, Ria Putri (2012). Pengaruh Kebijakan Dividen, Kebijakan Hutang dan Profitabilitas Terhadap Nilai Perusahaan Manufaktur Yang Terdaftar Di Bursa Efek Indonesia (BEI) Periode 2005-2010. Jurnal Riset Manajemen Sains Indonesia (JRMSI), Vol. 3, No.1: 1-17.

Mukherjee, Abishek., Bird, Ron \& Duppati, Geeta. (2017). Mandatory Corporate Social Responsibility: The India Experience. SSRN

Murnita, Putu Elia Meilinda, \& I Made Pande Dwiana Putra. (2018). Pengaruh Corporate Social Responsibility terhadap Nilai Perusahaan dengan Profitabilitas dan Leverage sebagai Variabel Pemoderasi. E-Jurnal Akuntansi Universitas Udayana Vol.23.2.

Nahda, Katiya. \& D. Agus Harjito. (2011). Pengaruh Corporate Social Responsibility Terhadap Nilai Perusahaan dengan Corporate Governance Sebagai Variabel Moderasi. Vol 15 No 1

Nofrita, Ria. (2013). Pengaruh Profitabilitas Terhadap Nilai Perusahaan dengan Kebijakan Deviden Sebagai Variabel Intervening (Studi Empiris Pada Perusahaan Manufaktur Yang Terdaftar Di Bei), Skripsi. Universitas Negeri Padang.

Nurrahman, Tias, Diamonalisa Sofianty, \& Edi Sukarmanto. (2018). Pengaruh Profitabilitas Terhadap Nilai Perusahaan. Fakultas Ekonomi dan Bisnis, Universitas Islam Bandung. ISSN: 2460-6561

Puspaningrum, Yustisia. (2017). Pengaruh Corporate Social Responsibility dan Kepemilikan Manajerial Terhadap Nilai Perusahaan dengan Profitabilitas dan Ukuran Perusahaan Sebagai Variabel Moderating (Studi Empiris Pada Perusahaan Pertambangan Di Bursa Efek Indonesia). Jurnal Profita Edisi 2

Rai, S, \& Bansal, S. (2014). An analysis of corporate social responsibility expenditure in India. Economic and Political Weekly, 49-50.

Rizqia, D. A., dkk. (2013). Effect of Managerial Ownership, Financial Leverage, Profitability, Firm Size, and Investment Opportunity on Dividend Policy and Firm Value. Research Journal of Finance and Accounting. Vol. 4 (11), hal 120-130.

Roitto, Artturi. (2013). Factors Effecting Corporate Social Responsibility Disclosure Ratings: An Empirical Study Of Finnish Listed Companies, Thesis. Accounting Oulu Business School.

Romana, Suci. (2017). Pengaruh Corporate Social Responsibility Terhadap Nilai Perusahaan dengan Profitabilitas Sebagai Variabel Moderating (Studi Empiris Perusahaan Sektor Pertambangan Yang Terdaftar Di Bursa Efek Indonesia Periode 2011-2015), Artikel IImiah. Universitas Pasir Pengaraian Rokan Hulu.

Saidi. (2004). Faktor-Faktor yang Mempengaruhi Struktur Modal pada Perusahaan Manufaktur yang Go Public Di BEJ tahun 1997-2002. Jurnal Bisnis dan Ekonomi, Vol.11. Hal 44-58. 
Jurnal Personalia, Financial, Operasional,

Marketing dau Sistern Informasi

Performance. Volume 27 Nomor 1 Tahun 2020, 51-59

Sari, Kartika Hadiyanti Wulan. (2015). Pengaruh Profitabilitas Terhadap Nilai Perusahaan Dengan Kebijakan Dividen Sebagai Variabel Intervening Pada Perusahaan Lq45 Di Bursa Efek Indonesia, Artikel Ilmiah. Sekolah Tinggi Ilmu Ekonomi Perbanas Surabaya.

Scholtens, B. (2008). A Note on The Interaction Between Corporate Social Responsibility and Financial Performance. Ecological Economics 68. pp.46- 55

Setiabudi, Andi, \& Dian Agustia. (2012). Fundamental factors of firm value. Journal of basic and applied scientific research.

Syamni Ghazali, Wahyuddin, Damanhur, \& Ichsan. CSR and Profitability in IDX Agricultural Subsectors. In Proceedings of MICoMS 2017. Published online: 11 Jul 2018; 511-517.

Umar, Safira. (2018). Pengaruh Profitabilitas Dan Leverage Terhadap Alokasi Dana Corporate Social Responsibility Dengan Board Gender Sebagai Variabel Moderasi (Studi Empiris pada Perusahaan Sektor Keuangan yang Terdaftar di Bursa Efek Indonesia Tahun 2014-2016), Skripsi. UIN Maulana Malik Ibrahim Malang.

Wijaya, Bayu Irfandi \& I.B. Panji Sedana. (2015). Pengaruh Profitabilitas Terhadap Nilai Perusahaan (Kebijakan Dividen dan Kesempatan Investasi Sebagai Variabel Mediasi). E-Jurnal Manajemen Unud, Vol.4, No.12.

Wu, Meng-Wen \& Chung-Hua Shen. (2013). Corporate social responsibility in the banking industry: Motives and financial performance. Journal of Banking \& Finance, vol. 37, issue 9, 3529-3547

Zallom, Bilal Fayiz Omar Nidal Omar. (2016). Corporate social responsibility and market value: evidence from Jordan. Journal of Financial Reporting and Accounting, Vol. 14 Issue 1. 